\title{
Antibacterial activity of Zataria multiflora essential oil and its main components against Pseudomonas aeruginosa
}

\author{
MOHADDESE MAHBOUBI*, REZVAN HEIDARYTABAR, ELAHEH MAHDIZADEH
}

\author{
Department of Microbiology \\ Medicinal Plant Research Center of Barij \\ Kashan, Iran \\ *corresponding author: phone: +98 864446 5112, fax: +98 864446 5187, e-mail: mahboubi1357@yahoo.com, \\ mahboubi@barijessence.com
}

\section{Summary}

Introduction: In Iranian traditional medicine, Zataria multiflora Boiss (Lamiaceae family) is reputed due to its antiseptic effects.

Objective: The purpose of this study was to evaluate the antibacterial and biofilm killing effects of Z. multiflora essential oil and main components against Pseudomonas aeruginosa.

Methods: The main components of essential oil were identified by gas chromatography (GC) and gas chromatography-mass spectrometry (GC-MS). The antibacterial properties of Z. multiflora oil and main components were determined by assessing the MIC and MBC values, and their inhibition percent of biofilm killing effects were determined by the evaluation of optical density. The role of each main component in these activities was determined according to the chemical profiles of essential oil.

Results: Thymol (38.7\%), carvacrol (30.6\%), and p-cymene (8.3\%) were main components of twenty five components of essential oil. Carvacrol had the higher role in antibacterial activity against $P$. aeruginosa, followed by thymol. $P$-cymene enhanced the antibacterial activities of thymol and carvacrol against $P$. aeruginosa. Carvacrol showed the weak role in biofilm killing effect. In spite of the low antibacterial activity of $p$-cymene against $P$. aeruginosa, it can enhance the antibacterial activity of thymol or carvacrol.

Conclusion: Z. multiflora essential oil can be used for the management of $P$. aeruginosa infections. Determining the precise role of each components needs investigating in their behavior in different media.

Key words: Zataria multiflora, thymol, carvacrol, biofilm, p-cymene, pyocyanin 


\section{INTRODUCTION}

Pseudomonas aeruginosa, as an opportunistic Gram-negative bacteria with high intrinsic antibiotic resistance and adaptability [1], is the major risk factor of many infections of soft tissues, urinary tract and respiratory systems, otitis externa, diabetic patients and gives rise to infections such as chronic obstructive pulmonary diseases, cystic fibrosis and bacteremia in humans [1]. The high mortality ranging from 18 to $61 \%$ is reported for $P$. aeruginosa infections [2].

Multitude of virulence factors such as flagella, type IV pili, LPS, proteases, lipase, pyocyanin, quorum sensing, alginate and forming the biofilm structure are responsible for $P$. aeruginosa infections [3]. Alginate production and biofilm formation are recognized as the most important virulence factor in $P$. aeruginosa related chronic infections. The complex structures of biofilms in $P$. aeruginosa as well as the signaling systems enable it to withstand against immune defense and antibiotics [4]. A blue green pigment of pyocyanin can interfere with some pathways such as host cell electron transport system and redox cycle in humans [1]. These mechanisms along with its intrinsic and acquired drug resistance to many classes of antibiotics make $P$. aeruginosa infections so difficult to treat [5].

Many natural or synthetic products have been subject of studies on overcoming the antibiotic resistance of $P$. aeruginosa infections [6]. Among them, essential oils with high phenolic content have exhibited the acceptable antibacterial activities against $P$. aeruginosa infections [7].

Zataria multiflora Boiss (Lamiaceae) is a plant with high total phenolic content and different preparations are been used in Iranian Traditional Medicine as anti-infectious agent for treatment of infections [8]. The antimicrobial activities of $Z$. multiflora essential oil was confirmed against different kinds of microorganisms (Staphylococcus aureus, S. saprophyticus, S. epidermidis, Bacillus subtilis, B. cereus, Listeria monocytogenes, Escherichia coli, Salmonella typhimurium, Shigella dysenteriae, S. flexneri, Klebsiella pneumoniae, Proteus vulgaris, Enterobacter aerogenes, Vibrio cholerae Inaba, Pseudomonas aeruginosa, Aspergillus niger, A. flavus, Candida albicans) from vaginal tract, oral cavities, skin infections [9]. The antimicrobial activity of $Z$. multiflora essential oil against $P$. aeruginosa was the subject of some studies. The antibacterial effects of $Z$. multiflora methanol extract against IMP-type metallo-beta-lactamase
(MBL)-producing $P$. aeruginosa [10] was confirmed. The results of different studies showed that $P$. aeruginosa had been less sensitive to $Z$. multiflora essential oil than other microorganisms [1113]. The $\mathrm{MIC}_{50}$ of $Z$. multiflora essential oil was reported as $31 \mu \mathrm{g} / \mathrm{ml}$ against $P$. aeruginosa [11]. Z. multiflora essential oil with carvacrol (37\%), pcymene (15\%), thymol (3.3\%) had the inhibition zone of $10.7 \mathrm{~mm}$ and MIC and MBC values of 64, $128 \mu \mathrm{g} / \mathrm{ml}$ [13]. Z. multiflora essential oil had the inhibition zone diameters of $11.7 \pm 0.6 \mathrm{~mm}$ and MIC, MBC values of $1,2 \mu \mathrm{l} / \mathrm{ml}$ [12].

The aim of this study was to evaluate the antibacterial and anti-biofilm activities of $Z$. multiflora essential oil and main components against $P$. aeruginosa in in vitro conditions. For the determination of the role of each main component of $Z$. multiflora essential oil, the chemical profiles of its essential oil was determined by GC and GC-MS.

\section{MATERIAL AND METHODS}

\section{Plant material, essential oil extraction and its analysis by GC and GC-MS}

Z. multiflora full flowering aerial parts were collected from Barij Essence Research Farm (Kashan, Iran) in May 2015. The identified herbarium sample was kept under voucher number 189 at the Herbarium Center of Agriculture Department, Research Center of Barij, Kashan, Iran.

For the extraction of the essential oil, dried aerial parts (100 g) of plant were subjected to hydro-distillation method by Clevenger type apparatus for $4 \mathrm{~h}$. The essential oil was extracted and dried using anhydrous sodium sulfate. The essential oil was stored in tightly closed dark vial until the analysis.

The chemical composition of essential oil was identified using GC and GC/MS apparatuses by Agilent technology (HP) 6890 system, with HP5MS capillary $(60 \mathrm{~m}-0.25 \mathrm{~mm}$ i.d., film thickness $0.25 \mathrm{~mm})$. The oven temperature program was initiated at $40^{\circ} \mathrm{C}(1 \mathrm{~min})$, then increased to $230^{\circ} \mathrm{C}$ (rate of $3^{\circ} \mathrm{C} / \mathrm{min}$ ) and held for $10 \mathrm{~min}$. Helium was the carrier gas at a flow rate $1.0 \mathrm{ml} / \mathrm{min}$. The detector and injector temperatures were 250 and $230^{\circ} \mathrm{C}$, respectively. The compounds of the essential oil were identified by comparison of their retention indices (RI) and mass spectra fragmentation with those on the stored Wiley $7 \mathrm{n} .1$ mass computer library, and National Institute of Standards and Technology [14]. 


\section{Antibacterial evaluation of $Z$. multiflora es- sential oil and its main components against P. aeruginosa}

Pseudomonas aeruginosa ATCC 27853 was used as standard bacteria in this investigation. Antibacterial evaluations were performed by micro-broth dilution assay. Thymol (T), carvacrol (C), p-cymene (P) (Sigma-Aldrich Co. LLC.) and Z. multiflora essential oil (ZM) were used for all antibacterial screenings. The quota of each component $(\mathrm{T}, \mathrm{C}, \mathrm{P})$ and their combination forms (CP, TP, TCP, TC) in essential oil were estimated based on chemical profile of analyzed essential oil. The stock solutions of these compounds $(64 \mu \mathrm{l} / \mathrm{ml})$ were prepared in dimethyl sulfoxide (DMSO).

For the determination of MIC and MBC values, micro-broth dilution assay was used. The stock solutions for compounds were diluted twofold serially in Muller Hinton Broth (8-0.125 $\mu \mathrm{l} / \mathrm{ml})$. After shaking, $100 \mu$ of diluted components was added separately to each well of 96-well micro titer plates. Bacterial suspension were diluted to $10^{6} \mathrm{CFU} / \mathrm{ml}$ and then $100 \mu \mathrm{l}$ of bacterial suspension was added to each well and incubated at $37^{\circ} \mathrm{C}$ for $24 \mathrm{~h}$. MIC values were defined as the lowest concentration of compound that inhibit the bacteria growth after $24 \mathrm{~h}$. MBC values were determined using the first well showing no growth on nutrient agar [15]. The growth Inhibitory percent (I\%) of $Z$. multiflora essential oil and components were determined by evaluating the $\mathrm{OD}_{600}$ of each sub-inhibitory concentration via this equation:

$$
\left[\left(\mathrm{OD}_{\mathrm{C}}-\mathrm{OD}_{\mathrm{w}}\right) / \mathrm{OD}_{\mathrm{C}}\right]^{*} 100=\mathrm{IP} \%
$$

where $\mathrm{OD}_{c}$ is the OD of control, $\mathrm{OD}_{\mathrm{w}}$ is $\mathrm{OD}$ of each well at sub-inhibitory concentration.

\section{Biofilm killing effects of $Z$. multiflora essential oil and its main components}

The bacterial biofilms were established by inoculating the bacterial suspension $\left(10^{6} \mathrm{CFU} / \mathrm{ml}\right)$ into the wells of micro titer plates and incubating at $37^{\circ} \mathrm{C}$ for $24 \mathrm{~h}$. After that, the culture media were removed and the wells were washed with distilled water to remove the planktonic cells. The diluted compounds (1-0.125 $\mu \mathrm{l} / \mathrm{ml})$ were added to wells and they were incubated at $37^{\circ} \mathrm{C}$ for $24 \mathrm{~h}$, again. The biofilm staining with crystal violet and estimating the biofilm killing effects was performed as below [16]. For staining the biofilms, crystal violet $(0.1 \%)$ was poured into the dried wells of plates and incubated for $10 \mathrm{~min}$. The crystal violet was removed, rinsed and well dried. After inserting acetic acid (30\%) into wells the biofilm killing effects of each compounds were estimated by determining the $\mathrm{OD}_{550}$ of each well in comparison with control wells (bacterial wells without essential oil).

\section{Statistical analysis}

All experiments were performed in triplicate and means of triplicate were used for drawing all diagrams. For the determination, the role of each main component in anti-pseudomonal effect of $Z$. multiflora essential oil, the results of $\mathrm{OD}_{600}$ related to bacterial growth in different concentration of compound were statistically analyzed by SPSS software (v. 17, Chicago, IL, USA). One-way ANOVA test was used to compare the difference between compounds and the $\mathrm{p}_{\text {value }}$ were calculated. The results were significant at level 0.05 .

Ethical approval: The conducted research is not related to either human or animal use.

\section{RESULTS}

The yield of essential oil was $2.3 \%(w / v)$. Twenty five components were identified in Z. multiflora essential oil that represents $99.7 \%$ of total oil composition. Thymol (38.7\%), carvacrol (30.6\%), and $p$ cymene $(8.3 \%)$ were main components of essential oil, followed by $\gamma$-terpinene (2.8\%), trans-caryophyllene $(2.1 \%)$ and $\beta$-myrcene (1.7\%), respectively (tab. 1).

In micro-broth dilution assay, Z. multiflora essential oil, thymol, carvacrol, thymol+carvacrol, carvacrol $+p$-cymene, thymol $+p$-cymene, and thymol+carvacrol $+p$-cymene had the same MIC and $\mathrm{MBC}$ values $(2,4 \mu \mathrm{l} / \mathrm{ml})$ against $P$. aeruginosa. Among different compounds, only $p$-cymene had the higher MIC and MBC values than the other compounds $(4,8 \mu \mathrm{l} / \mathrm{ml})$. Therefore, $p$-cymene alone as third main component of $Z$. multiflora has played a little important role in its antibacterial activity against $P$. aeruginosa. In micro-broth dilution assay, inserting the $p$-cymene into thymol, carvacrol and thymol+carvacrol did not change the MIC and $\mathrm{MBC}$ values of related compounds (carvacrol $+p$-cymene, thymol $+p$-cymene, and thymol+carvacrol $+p$ cymene) (tab. 2). 
Table 1.

Chemical composition of Zataria multiflora essential oil

\begin{tabular}{|c|c|c|}
\hline Compound & Retention Index & Percent \\
\hline$\alpha$-Thujone & 916 & 0.9 \\
\hline$\alpha$-Pinene & 925 & 1.2 \\
\hline$\beta$-Pinene & 961 & 1.2 \\
\hline 3-Octanone & 968 & 0.3 \\
\hline$\beta$-Myrcene & 980 & 1.7 \\
\hline Phellandrene & 987 & 0.4 \\
\hline$\alpha$-Terpinene & 1001 & 0.6 \\
\hline$\rho$-Cymene & 1013 & 8.3 \\
\hline Limonene & 1017 & 0.5 \\
\hline 1,8-Cineole & 1023 & 0.9 \\
\hline$\gamma$-Terpinene & 1050 & 2.8 \\
\hline$\alpha$-Terpinolene & 1066 & 0.2 \\
\hline Linalool & 1077 & 1.3 \\
\hline $\begin{array}{l}\text { 2-mMethoxy-4-methyl-1- } \\
\text { (1-methylethyl)-benzene }\end{array}$ & 1192 & 1.5 \\
\hline Carvacrol methyl ether & 1202 & 1.3 \\
\hline Thymol & 1282 & 38.7 \\
\hline Carvacrol & 1299 & 30.6 \\
\hline Thymol acetate & 1393 & 1.0 \\
\hline Carvacryl acetate & 1346 & 0.8 \\
\hline trans Caryophyllene & 1392 & 2.1 \\
\hline Aromadendrene & 1403 & 1.3 \\
\hline$\beta$-Selinene & 1405 & 0.1 \\
\hline$\alpha$-Humulene & 1411 & 0.2 \\
\hline Ledene & 1440 & 0.8 \\
\hline Caryophyllene oxide & 1505 & 1.0 \\
\hline
\end{tabular}

Table 2.

Antibacterial activity of Zataria multiflora essential oil and main components against Pseudomonas aeruginosa

\begin{tabular}{lcc}
\hline \multirow{2}{*}{ Components } & \multicolumn{2}{c}{$\begin{array}{c}\text { Broth dilution assay } \\
(\mu \mathrm{l} / \mathrm{ml})\end{array}$} \\
\cline { 2 - 3 } & $\mathrm{MIC}$ & $\mathrm{MBC}$ \\
\hline Thymol (38.7\%) & 2 & 4 \\
\hline Carvacrol (30.6\%) & 2 & 4 \\
\hline p-Cymene (8.3\%) & 4 & 8 \\
\hline Thymol, carvacrol (38.7\%, 30.6\%) & 2 & 4 \\
\hline Thymol, $p$-cymene (38.7\%:8.3\%) & 2 & 4 \\
\hline Carvacrol, $p$-cymene (30.6\%:8.3\%) & 2 & 4 \\
\hline $\begin{array}{l}\text { Thymol, carvacrol, } p \text {-cymene } \\
(38.7 \%: 30.6 \%: 8.7 \%)\end{array}$ & 2 & 4 \\
\hline Z. multiflora essential oil & 2 & 4 \\
\hline
\end{tabular}

Determining the growth inhibitory percent (I\%) at sub-inhibitory concentration showed -among different compounds - that $p$-cymene with higher MIC and $\mathrm{MBC}$ values had the lower growth inhibitory percent than other combinations and Z. multiflora essential oil and the difference was statistically significant $(p<0.05)$. Carvacrol had a significant difference with carvacrol $+p$-cymene and thymol+carvacrol $+p$ cymene $(p<0.05)$, while there was no significant difference between thymol and thymol $+p$-cymene $(p>0.05)$. In fact, $p$-cymene increased the antibacterial activity of carvacrol against $P$. aeruginosa, while this increasing effect was not observed for combination thymol $+p$-cymene in contrast to thymol alone. Also, in this graph, the growth inhibitory effects of $38 \%$ thymol (corresponding amount in essential oil) and $30 \%$ carvacrol was equal against $P$. aeruginosa. In other word, lower concentrations of carvacrol had higher growth inhibitory effects than that of thymol in Z. multiflora essential oil against $P$. aeruginosa. Thymol+carvacrol, thymol, and thymol $+p$-cymene had the weaker effects on bacterial growth than that of thymol+carvacrol $+p$-cymene $(p<0.05)$. It means that $p$-cymene increased the antibacterial activity of thymol+carvacrol. There was a significant difference between the antibacterial activity of $Z$. multiflora essential oil and thymol+carvacrol $+p$-cymene $(p<0.05)$. Therefore, thymol+carvacrol $+p$-cymene had the stronger antibacterial activity against bacterial growth than that of $Z$. multiflora essential oil (fig. 1).

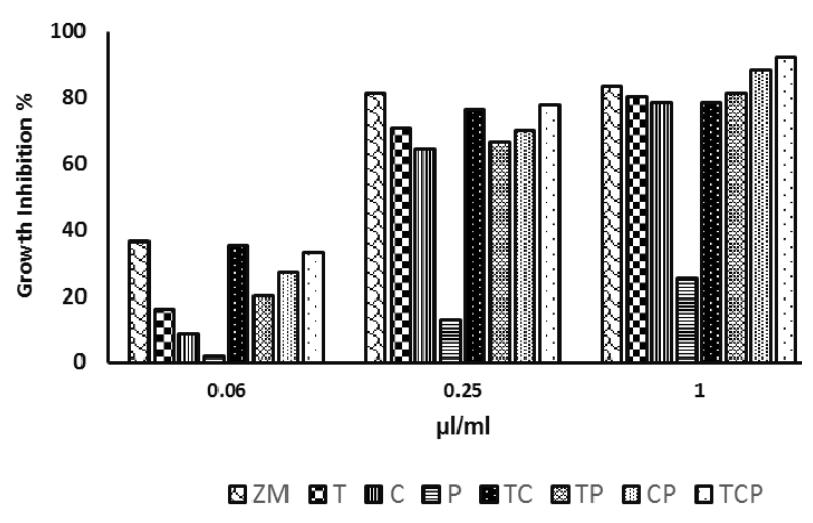

Figure 1.

The effects of sub-inhibitory concentrations of Zataria multiflora essential oil and corresponding components on the growth of Pseudomonas aeruginosa; $\mathrm{C}$ - carvacrol, $\mathrm{T}$ - thymol, $\mathrm{P}$ - p-cymene, ZM - Z. multiflora essential oil

In evaluating the biofilm killing effects of $Z$. multiflora essential oil and main components were shown than thymol, $Z$. multiflora essential oil and thymol+carvacrol $+p$-cymene had the best biofilm killing effects than the others. The biofilm killing effects of $p$-cymene and carvacrol $+p$-cymene was lower than the others (fig. 2). 


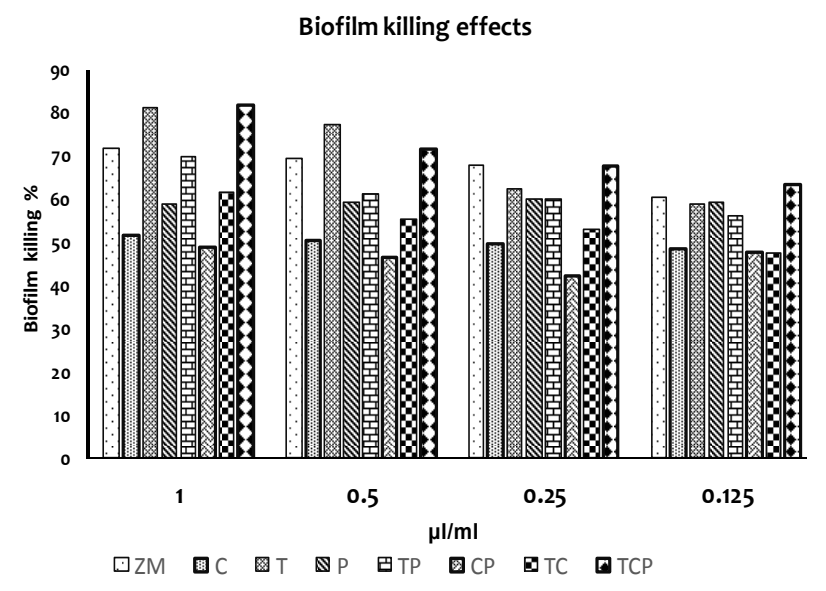

Figure 2.

The killing effects of Zataria multiflora essential oil and components on Biofilm formation; C - carvacrol, $\mathrm{T}$ - thymol, $\mathrm{P}$ - p-cymene, ZM - Z. multiflora essential oil

\section{DISCUSSION}

The antibacterial activity of $Z$. multiflora essential oil and its three main components were confirmed against $P$. aeruginosa. Although, the antibacterial activity of $Z$. multiflora essential oil against $P$. aeruginosa was the subjects of other studies [11-13] but the role of main components had not considered in other studies. The antibacterial activity of $Z$. multiflora essential oil is caused by killing effects against biofilm formation.

According to our results, the biofilm killing effects of $Z$. multiflora essential oil was related to carvacrol compound and then its thymol content. Although, enhancing the antibacterial effects of carvacrol and combination form of thymol and carvacrol in presence of $p$-cymene can't be neglected. $P$-cymene cannot considerate as an efficient antibacterial agent against $P$. aeruginosa, but it can increase the antibacterial activity of other compounds in Z. multiflora essential oil. The synergistic effects of $p$-cymene with carvacrol against different kinds of microorganisms have been confirmed [17, 18]. $P$-cymene with high affinity to cell membranes decreases the melting temperature of membranes [19] and perturbs the cells integrities [18].

The difference in antibacterial activities of carvacrol and thymol is maybe related to hydroxyl group position. Carvacrol, as the best antibacterial agent against $P$. aeruginosa, acts as trans membrane monovalent cations carrier of cell membranes $[18,20]$, and interacts with main physiological functions of bacterial cells $[21,22]$. Thymol, with hydroxyl group in Meta position had the lower antibacterial activity against $P$. aeruginosa than that of carvacrol.

Higher antibacterial activity of triple combination of thymol, carvacrol, and $p$-cymene in contrast to $Z$. multiflora essential oil showed that the other minor components of $Z$. multiflora essential oil had some role in its antibacterial activity and decreased the antibacterial activity of three main components of $Z$. multiflora essential oil.

Although, carvacrol had an important role in antibacterial activity of $Z$. multiflora essential oil against $P$. aeruginosa, but it had lower anti-biofilm activity than other components. One of probable mechanisms of this phenomenon may be non-polar structure of carvacrol and its insolubility in liquid media.

The antibacterial activity of $Z$. multiflora essential oil against $P$. aeruginosa is related to carvacrol and thymol, respectively. $P$-cymene as the third main component of this essential oil can increase the antibacterial effects of carvacrol and thymol-carvacrol combination. Due to the lower antibacterial effects of $Z$. multiflora essential oil than that of triple combination of thymol, carvacrol and $p$-cymene, the role of other minor components of essential oil in reducing the antibacterial effects of essential oil should be considered.

\section{ACKNOWLEDGEMENTS}

This study has been supported by Medicinal Plant, Research Center of Barij, Kashan, Iran. We are thankful to Mrs. Laleh Hejazi for financial support of study. Financial support for Medicinal Plant, Research Center of Barij Essence was essential for conducting this study. Authors' contributions: All the authors performed and prepared the draft of manuscript, data gathering, interpreting the findings.

Conflict of interest: Authors declare no conflict of interest.

\section{REFERENCES}

1. Gellatly SL, Hancock REW. Pseudomonas aeruginosa: new insights into pathogenesis and host defenses. Pathog Dis 2013; 67:159-73. doi: http:// dx.doi.org/10.1111/2049-632X.12033

2. Bassetti M, Righi E, Viscoli C. Pseudomonas aeruginosa serious infections: mono or combination antimicrobial therapy? Cur Med Chem 
2008; 15(5):7-22. doi: http://dx.doi.org/10.2174/ 092986708783503186

3. Ben Haj Khalifa A, Moissenet D, Vu Thien H, Khedher M. Virulence factors in Pseudomonas aeruginosa: mechanisms and modes of regulation. Ann Biol Clin 2011; 69:393-403. doi: http:// dx.doi.org/10.1684/abc.2011.0589

4. Rybtke MT, Jensen PO, Hoiby N, Givskov M, Tolker-Nielsen T, Bjarnsholt T. The implication of Pseudomonas aeruginosa biofilms in infections. Inflamm Allergy Drug Targets. 2011; 10:141-57. doi: http://dx.doi.org/10.2174/ 187152811794776222

5. Moore NM, Flaws ML. Antimicrobial resistance mechanisms in Pseudomonas aeruginosa. Clin Lab Sci 2011; 24:47-51.

6. Rasamiravaka T, Labtani Q, Duez P, El Jaziri M. The formation of biofilms by Pseudomonas aeruginosa: A review of the natural and synthetic compounds interfering with control mechanisms. Biomed Res Int 2015; 2015:17. doi: http:// dx.doi.org/10.1155/2015/759348

7. Nzeako BC, Al-Kharousi ZS, Al-Mahrooqui Z. Antimicrobial activities of clove and thyme extracts. Sultan Qaboos Univ Med J 2006; 6:33-9.

8. Zargari A. Medical Plants. 4th ed. Tehran University Publications 1990.

9. Mahboubi M. Zataria multiflora Boiss as medicinal plant. Germany: LAP Lambert Academic Publishing 2013.

10. Fallah F, Taherpour A, Borhan RS, Hashemi A, Habibi M, Sajadi Nia R. Evaluation of Zataria multiflora Boiss and Carum copticum antibacterial activity on IMP-type metallo-beta-lactamaseproducing Pseudomonas aeruginosa. Ann Burns Fire Disasters 2013; 26:193-198.

11. Gavanji S, Mohammadi E, Larki B, Bakhtari A. Antimicrobial and cytotoxic evaluation of some herbal essential oils in comparison with common antibiotics in bioassay condition. Integ Med Res 2014; 3:142-52. doi: http://dx.doi.org/10.1016/j. imr.2014.07.001

12. Mahboubi M, Kazempour N. In vitro antimicrobial activity of some essential oils from $\mathrm{La}$ - biatae family. J Ess Oil Bearing Plants 2009; 12:494-508. doi: http://dx.doi.org/10.1080/09720 60X.2009.10643750

13. Owlia P, Saderi H, Rasooli I, Sefidkon F. Antimicrobial characteristics of some herbal oils on Pseudomonas aeruginosa with special reference to their chemical compositions. Iranian J Pharm Res 2009; 8(2)107-14.

14. Adams RP. Identification of essential oils by gas chromatography quadrupole mass spectrometry. Allured Publishing Corporation, Carol Stream 2001.

15. CLSI. Methods for dilution antimicrobial susceptibility tests for bacteria that grow aerobically. In: Approved Standard M7-A8 EE, Wayne 2009.

16. Coffey BM, Anderson GG. Biofilm formation in the 96-well microtiter plate. Methods Mol Biol 2014; 1149:631-41. doi: http://dx.doi. org/10.1007/978-1-4939-0473-0_48

17. Rattanachaikunsopon P, Phumkhachorn P. Assessment of factors influencing antimicrobial activity of carvacrol and cymene against Vibrio cholerae in food. J Biosci Bioeng 2010; 110:6149. doi: http://dx.doi.org/10.1016/j.jbiosc.2010. 06.010

18. Ultee A, Bennik MHJ, Moezelaar R. The phenolic hydroxyl group of carvacrol is essential for action against the food-borne pathogen Bacillus cereus. Appl Environment Microbiol 2002; 68:1561-8. doi: http://dx.doi.org/10.1128/AEM.68.4.15611568.2002

19. Cristani M, D’Arrigo M, Mandalari G, Castelli F, Sarpietro MG, Micieli D et al. Interaction of four monoterpenes contained in essential oils with model membranes: implications for their antibacterial activity. J Agric Food Chem 2007; 5:6300-8. doi: http://dx.doi.org/10.1021/ jf070094x

20. Ben Arfa A, Combes S, Preziosi-Belloy L, Gontard N, Chalier P. Antimicrobial activity of carvacrol related to its chemical structure. Let Appl Microbiol 2006; 43:149-54. doi: http://dx.doi. org/10.1111/j.1472-765X.2006.01938x

21. Burt SA, van der Zee R, Koets AP, de Graaff $A M$, van Knapen F, Gaastra W et al. Car- 
vacrol induces heat shock protein 60 and inhibits synthesis of flagellin in Escherichia coli $\mathrm{O}_{157}: \mathrm{H}_{7}$. Appl Environ Microbiol 2007; 73:4484-90. doi: http://dx.doi.org/ 10.1128/ AEM.00340-07
22. Juven BJ, Kanner J, Schved F, Weisslowicz H. Factors that interact with the antibacterial action of thyme essential oil and its active constituents. J Appl Bacteriol 1994; 76:626-31. doi: http:// dx.doi.org/0.1111/j.1365-2672.1994.tb01661.x

\title{
Aktywność antybakteryjna olejku eterycznego z Zataria multiflora i jego głównych składników przeciwko Pseudomonas aeruginosa
}

\author{
MOHADDESE MAHBOUBI*, REZVAN HEIDARYTABAR, ELAHEH MAHDIZADEH
}

Department of Microbiology

Medicinal Plant Research Center of Barij

Kashan, Iran

*autor, do którego należy kierować korespondencję: tel.: +98 864446 5112, faks: +98 864446 5187,

e-mail: mahboubi1357@yahoo.com, mahboubi@barijessence.com

\section{Streszczenie}

Wstęp: Zataria multiflora Boiss (rodzina Lamiaceae) jest cenionym środkiem antyseptycznym w irańskiej medycynie tradycyjnej.

Cel: Celem tej pracy było określenie działania antybakteryjnego oraz niszczącego biofilm olejku eterycznego i innych podstawowych składników $Z$. multiflora przeciwko Pseudomonas aeruginosa.

Metody: Najważniejsze składniki olejku eterycznego zostały określone za pomocą chromatografii gazowej (GC) i chromatografii gazowej sprzężonej ze spektrometrią masową (GC-MS). Właściwości antybakteryjne olejku eterycznego i głównych składników Z . multiflora zostały określone przez oznaczenie wartości MIC i MBC. Efekt niszczenia biofilmu określono za pomocą gęstości optycznej. Rolę każdego z głównych składników określono zgodnie z profilami chemicznymi olejków eterycznych.

Wyniki: Olejek eteryczny Z. multiflora tworzy 25 składników, a głównymi są tymol (38,7\%), karwakrol $(30,6 \%)$ i $p$-cymen $(8,3 \%)$. Karwakrol miał największy udział w działaniu antybakteryjnym przeciw P. aeruginosa, kolejnym był tymol. $P$-cymen wzmacniał działanie antybakteryjne tymolu i karwakrolu przeciwko $P$. aeruginosa. Karwakrol wykazywał słabe działanie przeciwko biofilmowi. Oprócz niskiego poziomu aktywności antybakteryjnej przeciwko $P$. aeruginosa, $p$-cymen może wzmacniać działanie antybakteryjne karwakrolu.

Wnioski: Olejek eteryczny z Z. multiflora może być stosowany w leczeniu infekcji P. aeruginosa. Określenie dokładnej roli każdego składnika wymaga badania ich działania na różnych podłożach.

Słowa kluczowe: Zataria multiflora, tymol, karwakrol, biofilm, p-cymen, piocyjanina 